Check for updates

AUTHOR:

Johann Louw ${ }^{1}$ iD

\section{AFFILIATION:}

'Department of Psychology,

University of Cape Town, Cape Town, South Africa

\section{CORRESPONDENCE TO:}

Johann Louw

EMAIL:

johann.louw@uct.ac.za

\section{DATES:}

Received: 07 Feb. 202

Revised: 19 May 2021

Accepted: 23 May 2021

Published: 29 Sep. 2021

\section{HOW TO CITE:}

Louw J. A thesis embargoed:

Personnel research and ideology

in South Africa after World War II.

S Afr J Sci. 2021;117(9/10), Art.

\#9512. https://doi.org/10.17159/

sajs.2021/9512

\section{ARTICLE INCLUDES:}

囚 Peer review

$\square$ Supplementary material

\section{DATA AVAILABILITY:}

$\square$ Open data set

$\square$ All data included

$\square$ On request from author(s)

$\square$ Not available

凶 Not applicable

\section{EDITORS:}

Chrissie Boughey (iD)

Jenni Case iD

\section{KEYWORDS:}

history, personnel research, African

civil servants, apartheid, NIPR

FUNDING:

National Research Foundation of South Africa (grant no. 119117)

\title{
A thesis embargoed: Personnel research and ideology in South Africa after World War II
}

\begin{abstract}
Ten years after the conclusion of World War II, the Department of Native Affairs of the National Party government of South Africa sponsored research into the selection of African civil servants. The study was conducted by Rae Sherwood, under the auspices of the National Social Research Council, and the National Institute for Personnel Research. In 1960, Sherwood submitted the work to the University of the Witwatersrand to obtain a PhD degree. Two government departments objected to the award of the degree. In this paper, I recount the history of the research, explaining that the acceleration of the apartheid project between 1948 and 1961 played a significant role in the controversy that developed. The paper furthermore illustrates the difficulties faced by social scientific research under repressive political conditions, and the need for a more nuanced view of the psychological research of the National Institute for Personnel Research in South Africa at the time.

\section{Significance:}

- The history of South Africa's research organisations has been of interest for a long time. This study recalls the history of an unknown chapter in the history of the National Institute for Personnel Research, based on a PhD submission kept under embargo in the archives of the University of the Witwatersrand. The study was methodologically sophisticated, rich in data, but controversial in its findings, at least as it reflected on the policies pursued by the apartheid government after World War II. It adds another contextual element to the type of work conducted by the Institute.
\end{abstract}

\section{Introduction}

In July 1960, Rae Sherwood submitted a PhD thesis, 'The African Civil Servant - A Socio-Psychological Study', to the University of the Witwatersrand. ${ }^{1}$ In an interview I conducted on 23 August 1983 with Dr Sherwood in London, she mentioned that initially the National Party government refused permission for the research to be published as a PhD and that she had to reapply in the 1970s to obtain permission for the work to be considered for the degree. The degree was awarded in 1973, but she reported that even then the government placed it under an embargo. In 1995, I asked the University library whether the thesis was available for perusal, only to be informed that the thesis was not for consultation. ${ }^{2}$ In 2008 , when I visited the University archives, a staff member showed me the thesis, sealed in a large brown envelope. In 2018, I formally asked the University to lift the embargo, as it was an absurdity to have an apartheid-era thesis treated like this. After consultation with and approval from the executors of Dr Sherwood's estate in 2018 and 2019, the University formally made the thesis available.

Before embarking on the PhD, Sherwood had completed her first degree at the University of the Witwatersrand in 1940 and a master's degree in human development at the University of Chicago in 1948. She also received training at the Tavistock Institute in London in 1946. The family left South Africa in 1959 for the USA and settled in the United Kingdom in 1961. After the Sharpeville shootings of 1960, a large number of professionals and semi-professionals left South Africa - an exodus often characterised as South Africa's 'brain drain'. The fate of her brother, Rusty Bernstein, demonstrated vividly the risks for those who opposed the government at this time: between 1956 and 1958 he appeared in the famous Treason Trial, and in 1960 he was detained without charge for almost five months during the post-Sharpeville state of emergency. In the UK, Sherwood held positions at the London School of Economics, Brunel University, the Tavistock Institute, and the University of Sussex. While at Sussex, under the auspices of the Columbus Centre, she conducted research, based on psychoanalytic interviews, on personality and racial attitudes of three British families. The work culminated in her major publication, The Psychodynamics of Race. ${ }^{3}$

Although the research study on African civil servants was only one among hundreds of studies conducted under the auspices of the South African National Institute for Personnel Research (NIPR) in the 1950s and 1960s, its history merits uncovering. For a start, a work that has been buried in the archives for so many years upon the instructions of the apartheid government justifies a closer look, for this reason alone. In addition, it may provide interesting information about personnel research conducted just after World War II.

Luruli and Mouton ${ }^{4}$ gave a useful overview of the early history of research institutes and funding in South Africa. The NIPR (initially called the National Bureau for Personnel Research) was established in April 1946 within the Council for Scientific and Industrial Research (CSIR), with Simon Biesheuvel as director. Its goal was to produce scientific research in personnel selection and management in a South African economy that was developing rapidly after World War II. The Institute's contract work included research for the mining industry, the Defence Force, and public service departments like the Post Office and the SA Railways and Harbours.

The present paper addresses two questions: What were the events that constituted the controversy surrounding the thesis? and What in the thesis elicited such a strong reaction from the government of the time? 


\section{Trouble with the thesis}

Sherwood recalled that the National Social Research Council (NSRC) made a grant available to study African civil servants, with an eye on selecting 'men who would be able civil servants, hardworking and honest and honourable' (Sherwood R 1983, personal communication, 23 August). The records of the NSRC in the National Archives show that, in May 1954, it approved a request from the Secretary of the Department of Native Affairs (DNA), Dr W.W.M. Eiselen, to conduct research on the selection and efficiency of the 'Bantu civil servant'. ${ }^{5}$

A Supervising Committee was approved by the Minister of Education, Arts and Science, which included the Director of the Bureau of Educational and Social Research as chair (S. Pauw, later replaced by P.M. Robbertse), P.A.W. Cook and A.C. Myburgh, both from the DNA, and S. Biesheuvel of the NIPR. The records of the Supervising Committee ${ }^{5}$ intimated that they were looking for an experienced researcher. Sherwood's master's degree from the University of Chicago, a good research record, and the fact that she represented the Union government at a UNESCO conference in Mexico, made her a good candidate to conduct the research in the eyes of the Committee. She was appointed as a part-time Senior Research Officer at the NIPR in July 1954, with the responsibility to lead the research under the direction of this Committee.

It is difficult to establish from the existing documentation why the DNA sought to improve the selection and training of African civil servants. The only direct evidence for the DNA's motivation is contained in an untitled document from April 1954. ${ }^{6}$ It stated (translated from Afrikaans) that the problem in South Africa and indeed in Africa was that 'Native personnel' were often appointed with no consideration of their intellect or aptitude for the tasks they had to fulfil. This had a negative impact on their work efficiency and prevented them from making a useful contribution to their developing societies. It therefore would be worthwhile if it were possible to identify 'gifted Natives' who could accept responsibility and who had an aptitude for their jobs, argued the unidentified author (compare Sherwood's statement above about able, hardworking, and honourable civil servants). The Department therefore proposed the development of psychological tests, according to this document, which were designed to determine what aptitudes were required for different jobs in the civil service. The DNA clearly was looking for a practically useful outcome: the delivery of psychological tests for the selection of African civil servants. The NIPR, with its extensive experience of developing such tests for the classification of African workers in the gold mining industry, was a logical choice to conduct the research.

The broader political context may provide further pointers as to the DNA's motivation for this research. The National Party in the early 1950s started to address the challenge posed by urbanisation and administration of black South Africans to its apartheid vision. The DNA, with a wide range of responsibilities covering African labour bureaux, housing, immigration, and tax collection, played an essential role in controlling this challenge. During the 1950s, the DNA grew from a relatively small department to 'a largely autonomous "state within a state"' $7(0.30)$, with a staffing complement of more than 3000 . Hendrik Verwoerd, who later would become Prime Minister, was appointed as the Minister of Native Affairs in 1950, to reorganise the Department into a much more efficient unit. Pose ${ }^{8}$ has argued that as a social scientist himself, Verwoerd was one of the most assertive champions of the powers of science as the basis for informed planning, and the need for bureaucrats to administer and control the urban African population.

At the start of the study the Supervising Committee interpreted its mandate quite broadly:

every factor which might be supposed to have a bearing on the efficiency of the Bantu civil servant .. would be investigated ... Before practical recommendations involving the selection, training and management of these workers could be made, it was essential that a very broad foundation of understanding of the social, cultural and psychological factors involved in work attitudes and job performance be established. ${ }^{9(p .1)}$
The motivation for framing the research in this way, broader than the DNA requested, cannot be ascertained from the documentation, but it clearly created an opportunity to extend the project beyond its narrow focus on selection and testing. The Supervising Committee, in broadening the scope of the study in this way, created essentially two studies: one aimed at developing tests for selecting African civil servants, requested by the DNA; and a more politically sensitive one in which the overall functioning of African civil servants in the DNA would be explored. It is not clear who convinced the Supervising Committee to re-direct the study along these lines, but, in her interview, Sherwood suggested that she had argued for such a broader study, and that the Committee had agreed to it. As it turned out, the development of psychological tests received much less attention than the social, cultural, and psychological factors mentioned above. For example, the NIPR published only an interim report on the 'selection and work efficiency of Bantu public servants' as late as December $1961 .{ }^{5}$ The DNA was less than impressed with this situation, as described below.

In the progress report for the period October 1956 to October $1957^{10}$, two project reports were included: a 43-page report on 'The Bantu Clerk: A study of role expectations', and 'Motivational analysis: A comparison of job attitudes among African and American professional and clerical workers'. The Committee recommended that the former be published in the Journal of Social Psychology ${ }^{11}$, while the second one was presented at the 1957 conference of the South African Psychological Association ${ }^{12}$. The report noted that approval to publish was obtained from Eiselen as Secretary of the DNA, indicating that the Department was at least informed about publications from the study.

Sherwood's intention to use the material to write a thesis was never a secret. In September 1955, the Supervising Committee noted that she requested to use material not covered by the report to the DNA for a doctoral thesis, but preferred that 'she should leave the matter over until she had completed the final report, and that a request containing details of the aspects involved would receive sympathetic consideration and would be submitted with the Committee's recommendations to the Department of Native Affairs'. ${ }^{13(p .2)}$

The project drew to an end by the early 1960s. Sherwood handed in the thesis in July 1960, without informing the Supervising Committee. The University records show that it was "based on a research project carried out in the National Institute for Personnel Research under the auspices of the National Council for Social Research'.14(p.1) In October 1960, the Secretary of the Department of Education, Arts and Science (DEAS) informed the Registrar of the University that it had come to their notice that Ms Sherwood had submitted a thesis for a PhD. ${ }^{15}$ It is not clear how it came to their notice; the Secretary wrote only that it was 'by accident'. The Registrar was asked whether it concerned the selection and efficiency of Bantu civil servants. The letter also pointed out that Sherwood was employed by an ad hoc committee (the Supervising Committee) of the NSRC, who had not given permission to use the results for her own purposes. Not only that, but the report on the research had not been completed and submitted.

Sherwood replied that it was her understanding from the beginning that she would be permitted to submit part of the work for a thesis, and that her request was supported by the Committee..$^{16}$ She had regularly discussed it with Biesheuvel as her supervisor and had applied to the University for admission to the $\mathrm{PhD}$ with his approval. She remarked that the thesis she submitted was very different from the report to be submitted to the NSRC, in that the report was oriented toward the practical problems of personnel selection, while the thesis was concerned with exploring a number of theoretical propositions as 'a contribution to science'. Furthermore, the interim report was completed in May 1960 while the thesis was submitted in July 1960

Biesheuvel also wrote to Robbertse ${ }^{17}$ as Chair of the NSRC and indicated that he too believed that Ms Sherwood had received permission to proceed with the thesis, and that she had always acted with his knowledge and approval. Biesheuvel reiterated that Sherwood's thesis was not about the selection of clerks, but on the development of personality. A month later, however, after scrutinising the documentation, Biesheuvel acknowledged to Robbertse that he might have been under 
a wrong impression and that Sherwood needed prior permission from Council to submit the thesis. ${ }^{18}$

The summary of the history of the project showed that Sherwood signed her contract on 5 October 1954. The contract stipulated, inter alia, that:

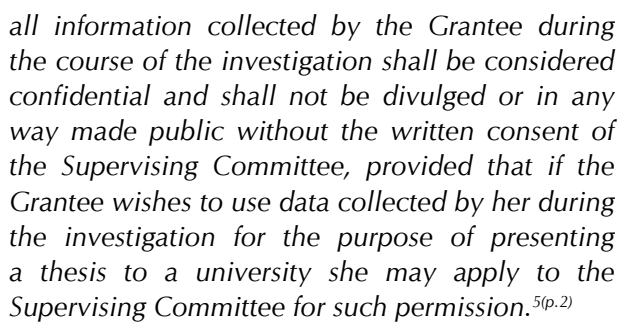

When the DEAS received the thesis from the University, they sent it to Eiselen, asking whether the thesis would embarrass the DNA (by that time Eiselen was no longer Secretary of the DNA). Eiselen's report ${ }^{19}$ gave the thesis serious consideration, providing an accurate and fair summary. He regarded much of the thesis as quite technical, with 'duistere vakterminologie' (dense jargon), and therefore unlikely to cause much harm. However, the main findings and conclusions were stated in very clear language (see the discussion on the results of the thesis below), which could be grasped quite easily in reviews and in the press. It may thus be, he concluded, that the Department had commissioned research to find methods to improve the efficiency with which the African clerks delivered services to their communities, but instead would be castigated for its role in administering 'unjust' government policies of separate development.

The Secretary of DEAS subsequently informed the University that permission could not be granted. ${ }^{20}$ Apparently, the Department of Bantu Administration and Development (DBAD), as the DNA was called by then, at this stage played no role in the decision. The Secretary for the DBAD wrote to the DEAS only on 7 September 1961 , noting that it had come to their attention that Sherwood had submitted a thesis, and asking for a copy. ${ }^{21}$ On 15 June 1962, the DBAD wrote that it could not give permission for the work to be submitted - nine months after the DEAS had reached the same decision. ${ }^{22}$

A few months later, the Secretary for the DBAD gave reasons to the DEAS for the recommendation..$^{23}$ It claimed that the data on which Sherwood reached her conclusions were incomplete and did not represent the views of the ordinary 'Bantu civil servant'. It was furthermore claimed that the findings were already dated, as many senior positions had been created in the civil service for 'Bantus' since the thesis had been completed (the letter cited no evidence to support this claim). Thus, stated the DBAD, releasing the thesis would not present an accurate picture of the situation and may in fact interfere in the Department's efforts to improve the situation. Briefly put, releasing the thesis would not have had any positive outcomes.

By September 1962, therefore, the fate of the thesis was settled: both government departments involved in the study refused permission for the thesis to be considered for a degree. In February 1962, the Secretary of the DEAS warned Sherwood in no uncertain terms, that 'Should you publish the material or make use of it in any way without the approval of the National Council for Social Research, the matter will be referred to the Attorney General...'24. The University of the Witwatersrand informed Sherwood that they could not accept the thesis without this approval.

As far as the original request from the DNA was concerned, in July 1961, the Secretary of the DEAS asked the President of the CSIR for copies of the complete set of psychological tests on the selection of African civil servants, as well as for a manual with information about norms, reliability, and validity. The letter stated further that the tests that had been sent to them (the NSRC files in the Archives contain nothing on this) were practically 'useless' and warned that no further funding would be forthcoming..$^{25}$

In December 1961, the Supervising Committee submitted an interim report on the development of these tests. ${ }^{26}$ It provided a summary of the research conducted, but with no mention of the developments around the thesis. It admitted that the final practical outcomes were disappointing, to say the least. According to the report, it was not yet possible to devise a set of personality tests that could be used for selection of African public servants, while the results of the tests of ability that were tried were not promising. The test results showed weak relationships with efficiency criteria such as productivity and job satisfaction considered in the study. Nevertheless, a preliminary battery of tests was finally constructed, named the 'Normal Battery'. It contained an omnibus set of tests: of intelligence, reading comprehension, vocabulary, spelling, and computation. Although not fully standardised, both Afrikaans and English language versions were available.

The response of the DBAD to these interim results was no less severe than the views of the DEAS a year before. The Secretary of the DBAD informed the Secretary of the DEAS that it was impossible to make use of the tests developed by the NIPR. The two versions of the Normal Battery, as well as the Interim Report, were thereby returned, and as far as the archival records go, this was the end of that part of the project. ${ }^{27}$

The thesis, and the award of a doctorate, not surprisingly, were very important to Sherwood, and she made two further attempts to get the government departments to overturn their refusals. In October 1965, she again requested the University to approach the DEAS. The Registrar wrote to the Secretary of the DEAS, reiterating the University's preparedness to regard the contents of the thesis as secret, to be released only to the examiners, and not to be placed on the library shelves. ${ }^{28}$ Robbertse approached Eiselen again, this time to ask whether in his opinion the thesis should go forward for examination. ${ }^{29}$ Eiselen replied within a week, stating that the thesis may very well be unacceptable to the DBAD, as it provided a twisted presentation of government policy. ${ }^{30}$ Although he did not want to comment on the academic merit of the thesis, he nevertheless remarked that the work did not show the necessary objectivity required from a serious academic researcher. This observation notwithstanding, he expected that the thesis most likely would be accepted as adequate for a doctoral degree, and if the University could keep it secret, it could be submitted.

Eiselen's prediction about the DBAD turned out to be accurate, as it informed the Secretary of the DEAS four months later that it could not approve submission. ${ }^{31}$ The DEAS waited until March 1968 to inform the University that the thesis still could not be accepted for submission towards a doctoral degree. ${ }^{32}$

Sherwood, however, was not ready to give up. Five years later she approached the University again, whereupon the Faculty of Arts appointed an ad hoc committee to consider the request. ${ }^{14}$ (As the records of the National Archives are silent about these events, I relied upon the University archives for a description of what transpired in 1973). The minutes of this committee's meeting show that when the thesis was submitted in 1960, three examiners were appointed before the process was halted: Professors Simon Biesheuvel and I.D. MacCrone of the University of the Witwatersrand, and Kurt Danziger of the University of Cape Town. The reports were generally very favourable, although some revisions were required. Then, on '14th September 1961, the Secretary for Education, Arts and Science wrote to confirm that permission would not be granted to the University to "consider" the thesis submitted by Mrs Sherwood for the Ph.D. degree'14(p.2). The minutes show that only when Sherwood and the University re-submitted their representation to the DEAS in 1973, was permission given, on 20 September 1973, that the work could be considered for a doctoral degree. The conditions, however, were that the work should be treated in the strictest of confidence, and was 'not to be reproduced or placed in the University library where general readers could have access to it'14(p.3). These were exactly the conditions the University was prepared to accept eight years previously to enable the thesis to proceed to examination.

At its meeting on 1 October 1973, the ad hoc committee considered the original examiners' reports and subsequent revisions of the thesis. The head of the Department of Psychology, Prof. Jack Mann, was requested to consider the thesis, the examiners' reports, and the candidate's revisions, to see whether Sherwood adequately addressed the concerns 
of the examiners. Upon receiving Mann's favourable report ${ }^{33}$, the committee decided, given the exceptional circumstances surrounding the thesis, that the degree be awarded, but under the conditions stipulated.

In conclusion, it is fair to say that the original purpose of the study, to develop psychological instruments that could be used in selecting African clerks for the DNA, came to an embarrassing end. The Interim Report referred to above arrived six years after the study was launched and was brief and cursory. Apart from the two tests, with no data on norms and no manual, there was not much that the Department could use, as the authors of the Report in fact acknowledged themselves. By contrast, Sherwood's thesis consisted of 221 single-spaced pages, in which she presented a huge amount of qualitative and quantitative data, together with carefully developed arguments. It is difficult to avoid the conclusion that the thesis part of the project superseded the less ambitious aims that the DNA originally had in mind. As indicated earlier, the choice of the Supervising Committee to include social, cultural and psychological factors involved in work attitudes and job performance in the research set the research project on this path.

The second part of the paper explores the thesis itself, to find out why it was so troublesome and why the question arose whether its contents would be embarrassing to the DNA

\section{Results and conclusions of the thesis}

To establish 'the very broad foundation' that the Supervising Committee envisaged, Sherwood drew a large sample $(N=392)$ of African clerks, teachers, social workers, and nurses together to study middle-class social attitudes and values. The group of African clerks comprised all employees of the DNA in Johannesburg (57); a random sample of African clerks working for the DNA in Pretoria (26); all African clerks employed by the Johannesburg City Council (102); and an informal sample of similar employees of private firms in Johannesburg (20). Chapters 3, 4 and 5 of the thesis describe the results of this part of the study.

The 57 African men who were employed as clerks in the Johannesburg office of the DNA provided the data for the rest of the thesis (Chapters 7 to 10). The chapters cover themes such as personality, work ideology and motivation, role expectations, and work setting. 'Work setting' included supervision, and the study therefore also included 53 white employees of the DNA who supervised these 57 African clerks. The inclusion of white supervisors could not have been accidental. The NIPR, and Biesheuvel in particular, was alert to the inherent conflict between African workers and their white supervisors, originally arising from the NIPR's work within the gold mining industry. ${ }^{34}$

The term 'role conflict' perhaps best summarises the overall conclusion of the study, where conflict occurred between the roles demanded from African clerks by the official policies of the South African government, white supervisors within the Department, and the African public that the clerks served. Government and the supervisors placed 'a minimum emphasis upon African ability, self-determination, the exercise of initiative, and the full expression and development of African potential'1(p.209). The DNA instead expected the clerks to be compliant, dependent, and ingratiating to authority. The white supervisors reproduced this conflict, as they gave high ratings to those clerks who were passive and dependent, irrespective of how efficient and productive they were in the organisation. As a result, the men had many complaints and sources of dissatisfaction in their work situation. A conclusion that 'The research findings indicate that the civil servant clerks complain more often of grievances in connection with apartheid and the colour bar than they do of any other frustrations affecting them in their work situation'1(p.210) must have been especially unpalatable to the DNA.

The role conflict furthermore extended beyond the boundaries of the organisation, to their relations with the African public, Sherwood argued. Clerks in the DNA dealt almost exclusively with other Africans, in activities such as assisting Africans with completing the DNA's forms, receiving payments, registering official statistics, taking statements on various disputes, and acting as interpreters during interviews or in court. Because they had to enact hated government policies against the interests of the African public, they became the focus of the negative feelings and rejections of fellow Africans. Indeed, Sherwood pointed out that the data reflected the social situation in 1956, in which Africans regarded this Department with great hostility, and African clerks who worked for the Department were regarded as 'traitors' to the people, which caused them, at the personality level, acute conflict, and strain.

The wider implication was that working for the Department would be unattractive to certain types of personality, and people with these personality types would therefore not select it as a place of work. At the same time, even if people who did not exhibit these ideal personality types did apply, they were not selected or retained. Sherwood predicted that the conflict that these clerks experienced would only worsen because the political climate was changing for the worse in South Africa. In summary,

The evidence from this analysis is clear: the present role structured for the African civil servants both limits and impedes the efficiency of these employees, and hence of the organisation itself, and creates frustration, conflict, and constriction in the individuals who occupy these roles. ${ }^{(p .212)}$

This rich data-gathering strategy demonstrated the importance of taking social, cultural and psychological factors into account, as it showed:

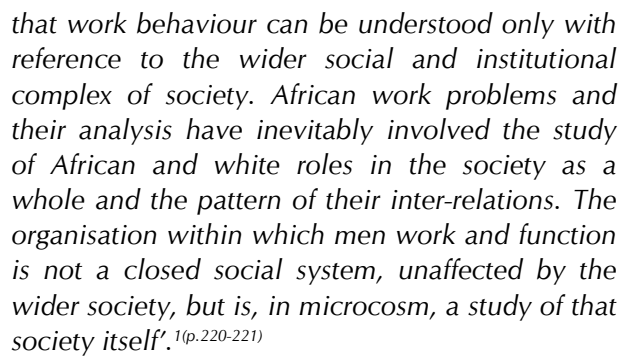

In the final paragraph, Sherwood explicitly drew out the implications of her study, not just for the African civil servants, but for black people in South Africa in general. This must have been the kind of statement Eiselen had in mind when he considered parts of the thesis as twisted presentations of government policy:

Where a society such as South Africa relegates subordinate status to a group of its citizens, and where discriminatory legislation affects their political, economic, and social lives, this study has shown that such subordinate groups cannot use their full potentialities constructively or creatively, and that their desire to contribute in full measure to the economic processes of that society will be undermined and weakened. To structure a role for a group of people so that their subordination is more important than their efficiency or their feelings of job satisfaction is to sacrifice not only their productive labour but also to undermine their morale and to build up hostilities within the group so that work behaviour comes to be an arena for the working through of their frustrations and resentments. ${ }^{1(p .221)}$

The paragraph quoted at some length above is as eloquent an argument against apartheid, based on social science data and theory, that one could find in 1960s South Africa. Even the use of the word 'citizens' was problematic, as black people belonged in their 'homelands' and not 'South Africa'. It also provides an explanation for why the results of the study were so troublesome, especially if seen against the background of a rapidly deteriorating relationship between the NIPR and the National Party government in the 1950s.

The NIPR in the 1950s was an anomaly among semi-government institutions, according to Coupe ${ }^{34}$. It increasingly ran into difficulties with the National Party government as it did not fall in line with apartheid ideology. For example, one NIPR staff member, Yette Glass, was refused 
a visa to present at an inter-African labour conference, because of her refusal to adopt the term 'Bantu' in her work. ${ }^{34(0.61)}$ Sherwood herself avoided the term 'Bantu' in the thesis, except in the questionnaire for white supervisors. She explained in a footnote that 'The word Bantu was used here in order not to antagonise the white subjects concerned'

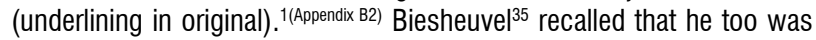
barred from attending at least two conferences on African labour and reminisced about the 'harassment' of the NIPR, which led to contracts from government virtually ceasing. He resigned from the NIPR in 1962. In an interview conducted 20 years later, he had this to say about his resignation: 'I went to SA Breweries in '62 for various reasons - don't want to talk about that. I fell out with the establishment, not the CSIR, but the Government'36(p.2)

\section{Conclusion}

Although this is one relatively small-scale study conducted by social scientists in South Africa in the 1950s, it nevertheless was worthwhile to explore its wider context and implications.

Posel characterised apartheid as a project of white supremacy and of Afrikaner nationalism. ${ }^{37(p .327)}$ This neatly captures a major contextual factor to explain why the project and thesis caused such trouble, namely that it contradicted quite fundamental aspects of apartheid's grand design. One such contradiction involved the policy that Africans did not belong as permanent residents in the urban areas of South Africa. This policy was largely administered by the DNA, from where the key participants in the Sherwood study were drawn. The research directly contradicted government policy, and in no uncertain terms, as Eiselen's second reading of its possible impact reflected.

An emphasis on science and being scientific is noticeable almost everywhere in the documents. Kingwill, in a history of the CSIR, commented that the the institute (the NIPR - JL) had played a pioneering role in the introduction of the scientific approach to personnel management practice in southern Africa'38(p.268). Sherwood commented in her interview on the importance of her work to be regarded as scientific. The focus on science is not altogether surprising, as 'being scientific' was a typically modern approach to a problem, which provided information for informed and rational planning. Earlier I quoted the work of Posel ${ }^{8}$, who demonstrated the importance of counting and classifying the population in the apartheid state.

Sherwood's research, however, shows that governing with science and numbers contains significant risks for a political party with an ideology like the National Party. The open-endedness of science contains an inherent threat that empirical data may contradict the ideological grounding of policies. In Posel's view,

We presume that scientific knowledge has served as one more powerful tool in the hands of the powerful - but the relation between scientific knowledge and political and economic power is more complex than that. The exercise of power was always contested, in many ways apartheid was a 'demented sort of rationalism'. ${ }^{8(p .138)}$

In terms of psychology, the NIPR's work in the 1950s and 1960s is often characterised as based on Elton Mayo's human relations approach. Fullagar ${ }^{39}$ claimed that the human relations focus in South African personnel psychology has often been described as having 'a cultural bias'. In other words, it 'has always tended to emphasize cultura/ rather than individual differences' (emphasis in original) because 'South African society encourages industrial psychologists to construct theories of black and white behaviour which ignore socio-political determinants'39(p.15). Sherwood's study shows that such a criticism requires more nuance, and that ignoring political and socio-economic factors was not a sine qua non of the NIPR's work. Certainly, the work done for her thesis cannot be accused of viewing 'the organization from a closed-system perspective'39(.22). It was explicitly not reductionistic; instead, it interpreted the troubles experienced by the African clerks within the full range of socio-cultural and political factors that determined their performance and efficiency: job reservation, apartheid legislation, unequal distribution of opportunities, etc. Indeed, Coupe stated that 'not all psychological research in South Africa is narrowly subservient to the interests of the dominant class, and work is occasionally published which is subversive of the ruling ideology ${ }^{\prime 34(0.43)}$. This is perhaps the most significant conclusion one could reach from these events, as made abundantly clear by the consequences for Sherwood's academic project.

\section{Acknowledgements}

This work is based on research supported in part by the National Research Foundation of South Africa (grant number 119117). I acknowledge the assistance of Adrian Brock of the University of Cape Town; Carol Crosley, the Registrar of the University of the Witwatersrand; and Nick and John Sherwood, sons of Dr Rae Sherwood.

\section{Competing interests}

I have no competing interests to declare.

\section{References}

1. Sherwood R. The African civil servant - A socio-psychological study [unpublished PhD thesis]. Johannesburg: University of the Witwatersrand; 1960

2. Louw J. South Africa. In: Baker D, editor. The Oxford handbook of the history of psychology. Oxford: Oxford University Press; 2012. p. 43-59.

3. Sherwood R. The psychodynamics of race: Vicious \& benign spirals Brighton: Harvester Press; 1980.

4. Luruli NM, Mouton J. The early history of research funding in South Africa: From the Research Grant Board to the FRD. S Afr J Sci. 2016;112(5/6), Art. \#2015-0097, 6 pages. http://dx.doi.org/10.17159/sajs.2016/20150097

5. National Archives of South Africa (NASA). Navorsing met betrekking tot die keuring van die Bantoestaatsamptenaar. Geskiedenis van die projek. [Research regarding the selection of the Bantu State official. History of the project.] NSRN Reference N/R/6/394 Part 3. Pretoria: NASA; 1960-1966. Afrikaans

6. National Archives of South Africa (NASA). Untitled document from the DNA 1954 April 13. Reference N/R/6/394 Part 1. Pretoria: NASA; 1954-1955.

7. Bonner P, Delius P, Posel D. The shaping of apartheid. Contradiction, continuity and popular struggle. In: Bonner P, Delius P, Posel D, editors. Apartheid's genesis, 1935-1962. Johannesburg: University of the Witwatersrand Press; 1993. p. 1-41

8. Posel D. A mania for measurement: Statistics and statecraft in the transition to apartheid. In: Dubow S, editor. Science and society in southern Africa. Manchester: Manchester University Press; 2000. p. 116-142.

9. National Archives of South Africa (NASA). A study of the Bantu Civil Servant - Report on progress for the year October 1956 - October 1957. Reference N/R/6/394/1 Part 1. Pretoria: NASA; 1954-1955.

10. National Archives of South Africa (NASA). Progress report to the Supervising Committee, October 1956 to October 1957. Reference N/R/6/394 Part 3. Pretoria: NASA; 1960-1966

11. Sherwood R. The Bantu clerk: A study of role expectations. J Soc Psychol. 1958;47:285-316. https://doi.org/10.1080/00224545.1958.9919247

12. Sherwood R. Motivational analysis: A comparison of job attitudes among African and American professional and clerical workers. Proc S Afr Psycho Assoc. 1956-7;7\&8:27-28.

13. National Archives of South Africa (NASA). Notes from the Supervising Committee meeting, September 1955. Reference N/R/6/394 Part 3. Pretoria: NASA: 1960-1966.

14. Minutes of a meeting of an ad hoc committee, dated 9 October 1973. University of the Witwatersrand, Faculty of Arts, Central Records Office, Archives Section, Document S73/811 (F.A. 102); 1973.

15. National Archives of South Africa (NASA). Letter of 3 October 1960 to the Registrar of the University of the Witwatersrand, Johannesburg. Reference N/R/6/394 Part 3. Pretoria: NASA; 1960-1966.

16. National Archives of South Africa (NASA). Letter of 14 November 1960 to the Supervising Committee. Reference N/R/6/394 Part 3. Pretoria: NASA 1960-1966. 
17. National Archives of South Africa (NASA). Letter of 7 November 1960 to P.M. Robbertse. Reference N/R/6/394 Part 3. Pretoria: NASA; 1960-1966.

18. National Archives of South Africa (NASA). Letter of 7 December 1960 to P.M. Robbertse. Reference N/R/6/394 Part 3. Pretoria: NASA; 1960-1966.

19. National Archives of South Africa (NASA). Letter of 31 July 1961 to the Secretary of DEAS. Reference N/R/6/394 Part 3. Pretoria: NASA; 1960-1966.

20. National Archives of South Africa (NASA). Letter of 14 September 1961 to the Registrar, University of the Witwatersrand. Reference N/R/6/394 Part 3. Pretoria: NASA; 1960-1966

21. National Archives of South Africa (NASA). Letter of 7 September 1961 to the Secretary of DEAS. Reference N/R/6/394 Part 3. Pretoria: NASA; 1960-1966.

22. National Archives of South Africa (NASA). Letter of 15 June 1962 to the Secretary of DEAS. Reference N/R/6/394 Part 3. Pretoria: NASA; 1960-1966.

23. National Archives of South Africa (NASA). Letter of 1 August 1962 to the Secretary of DEAS. Reference N/R/6/394 Part 3. Pretoria: NASA; 1960-1966.

24. National Archives of South Africa (NASA). Letter of 27 February 1962 to Rae Sherwood. Reference N/R/6/394 Part 3. Pretoria: NASA; 1960-1966.

25. National Archives of South Africa (NASA). Letter of 2 July 1961 to the President of the CSIR. Reference N/R/6/394 Part 3. Pretoria: NASA; 1960-1966.

26. National Archives of South Africa (NASA). The selection and work efficiency of Bantu public servants. Interim report, National Institute for Personnel Research, December 1961. Reference N/R/6/394 Part 3. Pretoria: NASA; 1960-1966

27. National Archives of South Africa (NASA). Letter of 25 September 1962 to the Secretary of the DEAS. Reference N/R/6/394 Part 3. Pretoria: NASA; 1960-1966.

28. National Archives of South Africa (NASA). Letter of 6 October 1965 to the Secretary of the DEAS. Reference N/R/6/394 Part 3. Pretoria: NASA; 19601966.
29. National Archives of South Africa (NASA). Letter of 20 October 1965 to W.M.M. Eiselen. Reference N/R/6/394 Part 3. Pretoria: NASA; 1960-1966.

30. National Archives of South Africa (NASA). Letter of 28 October 1965 to P.M. Robbertse. Reference N/R/6/394 Part 3. Pretoria: NASA; 1960-1966.

31. National Archives of South Africa (NASA). Letter of 28 February 1996 to the Secretary of the DEAS. Reference N/R/6/394 Part 3. Pretoria: NASA; 1960-1966.

32. National Archives of South Africa (NASA). Letter of 4 March 1968 to the Registrar, University of the Witwatersrand. Reference N/R/6/394 Part 3. Pretoria: NASA; 1960-1966.

33. Mann JW. Report on the revised thesis entitled: The African civil servant - A socio-psychological study submitted by Mrs R. Sherwood for the degree of Doctor of Philosophy. University of the Witwatersrand, Faculty of Arts, Central Records Office, Archives Section, Document S73/810 (F.A. 101): 1973.

34. Coupe S. Testing for aptitude and motivation in South African industry: The work of the National Institute for Personnel Research, 1946-1973. Bus Hist Rev. 1996;70:43-68. https://doi.org/10.2307/3117219

35. Biesheuvel S. Sherrington Club presentation on 12/8/88: Reminiscences about IQ testing and human groups. Handwritten document in Biesheuve Archives, University of the Witwatersrand, Johannesburg, Box AU8 BIE; 1988.

36. Biesheuvel S. Interview with I. van W. Raubenheimer. Transcript available in the Raubenheimer Collection, Special Collections Section, University of Stellenbosch Library, Box 399 'Industriële sielkundiges'; 1982.

37. Posel D. The apartheid project, 1948-1970. In: Ross R, Kelk Mager A, Nasson B, editors. The Cambridge history of South Africa. Vol. 2, 1885-1994. Cambridge: Cambridge University Press; 2012. p. 319-368.

38. Kingwill DG. The CSIR - The first 40 years. Pretoria: CSIR; 1990

39. Fullagar C. Organizational behaviour in South Africa: An historical overview. In: Barling J, editor. Behaviour in organizations. Johannesburg: McGraw-Hill; 1983. p. 3-26. 